\title{
The Scholar and the Pub Crawler: Revisiting the Debate between Ricoeur and Gadamer
}

\author{
John Arthos
}

With emendations and qualifications, Ricoeur accepted Habermas's four main criticisms of Gadamerian hermeneutics. The first three seem by now uncontroversial: philosophical hermeneutics does not take sufficient account of power and interest, mistakes ideology for misunderstanding, and gives too much weight to a prior ontological consensus. ${ }^{1}$ The fourth criticism, affirming the need for a critical social science as a balance to ontological hermeneutics, became a centerpiece of Ricoeur's own project and is still a nexus of fruitful debate. There could hardly be a claim against which Gadamer remained more passionately opposed, and I think the reason for this irreconcilable difference has to do with the fundamentally different function hermeneutics served for these two thinkers.

Ricoeur sought not only to bring hermeneutics closer to its original regional status as an art in dialogue with other arts but also cast it more narrowly as a scholarly enterprise of analysis and interpretation of signs, symbols, and texts. Gadamer conceived hermeneutics as having a scope analogous to the rhetorical humanism of the classical tradition, and so regarded it as a description of a general paideia. Like rhetoric, which is both a theory and a practice, hermeneutics is "the theory and also the practice" of understanding. ${ }^{2}$ The hermeneutical situation for him was a synonym for the human condition, descriptive more of its historical finitude and dependence on contingent judgment than on a textual tradition. In a way that Gadamer resists with all his energies, 
Ricoeur wants to bring hermeneutics into a close connection with the realm of expertise. This distinction between the hermeneutics of the discourse specialist and of the layperson, or the prudent citizen, is an easily overlooked difference that has enormous consequences.

Although Gadamer sees hermeneutics working at a number of different levels, he asserts in a variety of ways that hermeneutic understanding is not just about, but is "the way we experience one another, the way we experience historical traditions, the way we experience the natural givenness of our existence and of our world." Gadamer's way of knowing is "a knowledge that rises from the being of a person, his human existence, his character, the formulation of his

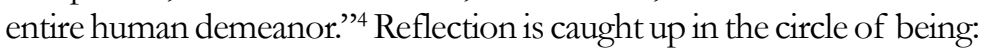
"The reflection that would constitute practical philosophy would nevertheless with inner necessity have to make the claim not only to know what the good is, but also to contribute to it. Thus it is in any event for the decision that faces a person in acting or abstaining: he wants to know what is best." " Hermeneutics "is not just a theory," but can be "understood as a teaching about a technical skill (Kunstlebre) in the manner of rhetoric too. Like rhetoric, hermeneutics can designate a natural capacity of human beings, and then it refers to the human capacity for intelligent interchange with one's fellows." "So it appears to me, heightened theoretic awareness about the experience of understanding and the practice of understanding, like philosophical hermeneutics and one's own self-understanding, are inseparable."7

In resisting the objectivity of empiricism and rationalism, Gadamer proposes an objectivity tied to the existential pathos of being human in a situation. ${ }^{8}$ One's comportment towards the world [sich verhalten $]$ is a question of finding one's bearings, a relation that finds its balance in a holding-back-from as much as holding to oneself. This kind of distance gives rise to the famous distinction between world and environment, but equally important is the strong emphasis this kind of distance places on what Gadamer is usually accused of ignoring or diminishing, that is, objectivity. Gadamer writes: "To have an orientation toward the world, however, means to keep oneself so free from what one encounters of the world that one can present it to oneself as it is." Reflective distance, objectivity, is at the heart of the dynamic of linguistic being. Certainly there is a gap, introduced by language, between the individual and the power to control meaning, but the equivocity of language also provides room for negotiating our precise relation to the world. Hermeneutic distance does not extract 
and dispose of the subjective elements of experience, but rather allows bumans to "bring into proportion, make communicable and place at a workable distance its threatening, overwhelming immediacy." 10 The text may be the paradigm of linguistic distance, as Ricoeur rightly maintains, but it is still one distance among many. It would be hermeneutically impossible to find a self-understanding that is not mediated. So this is not where the genuine break occurs between Gadamer and Ricoeur.

The true break occurs with what Gadamer understands as a difference of levels. In a debate with Ricoeur, Gadamer challenges Ricoeur's placement of analysis alongside understanding:

Well, you described the hermeneutic and the structuralist approaches, and then applied a hermeneutic also to that contrast. I could not see that it had the same level. I have no doubt that one can elaborate and use many forms of explanation. There is not just structuralism; there are many other ways to interpret a text. I certainly need a great deal of knowledge about language and historical conditions and cultural habits and so on, that is one thing. But to concretize all that in this unique statement or text that must recollect all these externalized and objectifiable aspects, to live through the meaning in concrete fullness, that is quite another thing. ${ }^{11}$

Ricoeur's effort to reintegrate method into the hermeneutic tradition pivots on his lifelong opposition to Dilthey's categorial separation of explanation and understanding in the disposition of scientific knowledge. ${ }^{12}$ In this schema, the natural sciences fall under the domain of explanation that is subject to the objective analysis of physical things, whereas humans can only be studied through interpretation, since the inner life is accessible through subjective understanding. Ricoeur wants to say at this point that human beings have no direct self-experience but must rely indirectly on signs for self-understanding. In correcting Dilthey, Ricoeur finds a mediating link between explanation and understanding in these "signs" of life, which are the objective traces of subjectivity and ultimately form texts amenable to structural analysis. With this link hermeneutics does not have to abandon epistemology in favor of ontology, but can engage the two in a productive relationship. Much of Ricoeur's effort through his life's work was the bridging of epistemology and ontology through the intermediary role of sign and text. In the course of his dialogues with Gadamer, Ricoeur may have 


\section{JOHN ARTHOS}

modified his initial position by stressing that explanation was subordinate to interpretation, but he never abandoned a characterization of explanatory analysis as a true science, and the character of this attribution gives Ricoeur's critical hermeneutics its decisive difference.

There can be no gainsaying the usefulness of structural analysis, of semiotics and linguistics, of the cooperation of the human sciences in interpretive practice, nor at a broader level, of the relevance of methodological rigor, techniques of measurement and proof, the splendid machinery of the social sciences for guarding against prejudice and false claims. But where Ricoeur and Gadamer part ways is the level at which expertise and methodological practice is put to use. In promoting humanism, Gadamer was not only saying that we must rely upon the authority of tradition, as Ricoeur summarizes it. ${ }^{13}$ Gadamer was also affirming the cardinal humanist principle that human beings are responsible for judgments that do not rely on the realm of the expert, judgments that take account of instrumental claims but ultimately take their own measure. Ricoeur also has a place for this kind of judgment, which he calls "attestation," but it figures differently in his picture of hermeneutics. We can pinpoint the place where Ricoeur diverges from Gadamer quite precisely in his own texts.

The hinge of Ricoeur's separation from German hermeneutics is his promotion of the written text as a moment of objectification distinctly different in kind from face-to-face dialogue. The separation of the text from the ties of authorship, both in terms of intention and context, gives the text an autonomy that a conversation lacks. The text is freed to a future engagement with readers, both in terms of their assimilation into its world, and their elaboration of new worlds. But the autonomy of the text also means that it no longer "finds its norm of intelligibility" in the author's world or intention, and this gives it a certain freestanding integrity. ${ }^{14}$ Before the text is restored to its living communication with a reader in a new context, it is available as "a worldless and authorless object" to be explained "in terms of its internal relations, its structure." 15

Ricoeur's departure from Gadamer is not over autonomy per se but over how this autonomy is to be used. For Ricoeur, the distance of the text is the occasion for the intercession of the scholarly task, an analytic mediation that is part of the structure of understanding itself. Certainly, and Gadamer would have no objection here, disciplinary sciences feed not only a research tradition but a general education, even if this double function is often troubled. But in Ricoeur, 
explanatory analysis is cast as a dialectical partner to the cultivation of understanding as a human competency. In the metaphorical language of textuality, he joins the scholarly work of textual analysis with the act of reading itself. Ricoeur fuses without remainder the explanatory work of research to the common human act of reading, listening, witnessing (literature, poetry, etc.). The integration of explanation and understanding yields a hermeneutics that is tied to the scholarly task. This seemingly minor point goes to the heart of Gadamer's objection. The scholarly task, the work of the expert, is suddenly positioned well above its hermeneutic paygrade. ${ }^{16}$

The equilibration of the general reader and the critic, historian, psychologist or sociologist passes almost imperceptibly in Ricoeur's arguments. In a paper titled, significantly, "Appropriation", it is the objectification of the text into an ideality separated from "a given speaker in a given situation" that leads to the division between explanation and understanding, and although the actualization into the life experience of the reader is neatly separated from the analytic practice, it is this very division which is labeled a dialectic. ${ }^{17}$ On the one hand, Ricoeur attaches the act of understanding to "anyone who can read," as befits the existential scope of textuality, and to this universality he attaches the work of the text in constructing subjectivity: "It is to receive an enlarged self" which is "the genuine object of interpretation."18 But, on the other hand, the role of scientific analysis elides with the personal experience of reading as if these two occurred as a matter of course on the same level: "It is necessary to have gone as far as possible along the route of objectification, to the point where structural analysis discloses the depth semantics of a text, before one can claim to 'understand' the text in terms of the 'matter' which speaks therefrom. The matter of the text is not what a naïve reading of the text reveals but what the formal arrangement of the text mediates. If that is so, then truth and method do not constitute a disjunction but rather a dialectical process." ${ }^{19}$ Notice how the act of "naïve reading" must be mediated by the work of structural analysis. Ricoeur says explicitly that structural analysis is what leads us from a "naïve reading" to "a learned reading." ${ }^{20}$ How can this transpire except through the ever-present intercession of the scholar, researcher, expert? Gadamer pinpoints this extraordinary demand in a debate with Ricoeur: "Finding a common language is not contributing to a new handbook of science or thought; it is sharing in a social act. ... For the critique of ideologies, psychoanalysis, and every radical form of critique should be and needs to be reintegrated into this basic 


\section{JOHN ARTHOS}

process of social life - a way which I call (in a manner I find satisfactory) hermeneutical." 21 This designation of what hermeneutical means leads us to what I regard to be the underlying division between Ricoeur and Gadamer with respect to the role of science.

The steady historical shift of hermeneutics from a specialized technique to a philosophy, with its enlistment into ontological reflection by Gadamer, gives it a certain shifting indeterminacy. Toward the end of his life, Gadamer was increasingly emphatic that hermeneutics was an art analogous to the ancient art of rhetoric and in many ways was an extension of rhetoric. Like rhetoric, it exhibited itself as an "innate ability" common to educated citizens. ${ }^{22}$ For Gadamer, Socratic ignorance meant, among other things, separation from the regime of the expert, and this extended to the claims of philosophy and philosophers. Just as Socrates refuted the pretensions of intellectual professionalism, so Gadamer modeled philosophical hermeneutics on the rhetorical competencies of the vir bonus, the good citizen. The "passion for questioning," on his view, is "a natural human tendency." 23 Perhaps the most explicit statements about this Socratic allegiance occur in the essay "The Incompetence of the Philosopher." Gadamer is disturbed by the assumption that "there are, or perhaps should be, particular kinds of people who practice philosophy, which is not the case. Philosophy is practiced by everybody .... Everywhere people are asking philosophical questions ... to which no one is in a position to give answers .... I am always amazed that the philosopher, in the academic sense of the word, is supposed to have a particular competence." 24 It is in the context of these remarks that he echoes, by way of criticism, Ricoeur's famous "conflict of interpretations": "The conflict is not between the specialized knowledge of some experts and the social reality of practical life, it is in humanity itself, in its questioning and errors." ${ }^{25}$ From this Gadamer concludes that "each and every one of us experiences in himself or herself the responsibility which we all bear and which we conceal from ourselves." 26

Now there is an interesting wrinkle in Gadamer's position on the amateurism of philosophy. He is insistent that there is a sharp division between practical philosophy and prudential practice, because philosophy, by thematizing prudence, is one step removed from it. Nevertheless, this second order function does not have as its necessary end an academic class of professionals, instead it is one means by which "we integrate ourselves into society through education." ${ }^{27}$ Everyone, on his view, needs to be reflective about their practice and to be formed 
by the habit of reflection.

Ricoeur, by contrast, separates the roles of the interpreting reader and the analyst: "Now, upon this understanding by which the author or reader 'makes' the metaphor is superimposed a scholarly explanation." 28 The second order task of analyzing the reception of texts is a "bringing to light the codes underlying this work of structuring that is carried through in company with the reader." ${ }^{29}$ This coding is reintegrated back into the reading, but we have already separated out the two tasks by a division of labor. The objectivity of the Habermasian social scientist remains a part of Ricoeur's paradigm of textual reception.

In Ricoeur's 1973 Interpretation Theory lectures, a major effort of his middle period to relate the various forms of textual discursivity through interpretive principles, hermeneutics is regarded quite unselfconsciously as a scholarly activity. Ricoeur seeks, without apology, "procedures for validation" focused on "the analytic structure of the text." ${ }^{30}$ With respect to all these formulations, it is appropriate, I would claim, to ask "who" it is that is doing the explanation or interpretation. Who is it that interprets a mythology by bringing out "the logic of the operations" that constitute "the structural law of the myth"? ${ }^{31}$ It is clearly not those who Ricoeur calls "the users of the narrative," but the structuralists who provide the depth semantics of the text. And because this whole project stands under the task of a science of signs, even the final informed interpretation belongs to "the world of the users of the narrative, which itself falls under other semiological disciplines that deal with social, economic, or ideological systems." ${ }^{2}$ The entire hermeneutic remains within disciplinary structures, and so it never needs to leave the circle of expert readers.

Gadamer sees hermeneutics as a broad orientation towards a liberal paideia for a community, while Ricoeur sees hermeneutics as a guiding approach to the systematic analysis of discourse in the scholarly enterprise. Since the transformative role of understanding is operative for both hermeneutics, they have a strong filiation. But, as we have seen, the differences of application open onto significantly different views of what hermeneutics itself is. It is hard to imagine that Ricoeur could think in terms of what Gadamer calls "hermeneutic experience." This phrase is simply a descriptor for a way of being-in-the-world; it is equivalent for him to our actual social condition. Ricoeur wants to foster a productive disposition for the sciences and the humanities in relation to each other. He is talking about how academics do their work, and that is a project at a very different level. One could extrapolate 


\section{JOHN ARTHOS}

out to transformations in the social order as a result of this reconfiguration, but those would be distant effects.

From an institutional perspective concerning the function hermeneutics serves at the level of institutions, Gadamer is, ironically, far more subversive and radical than Ricoeur. Ricoeur accepts to some extent the basic structure of the cultural formations responsible for the production of knowledge, given his reformist program for the interaction between the social sciences and the humanities. Gadamer is trying to overthrow these forms by returning to something closer to the pre-Enlightenment model of general education, removing the arts of rhetoric and hermeneutics from their location in the research university as specialized studies and opening them onto the praxis of a political culture. As idealized or naive as this program may be, it should not be confused with the turn hermeneutics took after Melanchthon where it became an art of textual interpretation. Heidegger and Gadamer completed the return to Melanchthon's pedagogic program of a hermeneutic rhetoric for the school curriculum, a return that was made possible by Schleiermacher's universalization of hermeneutics.33 The countertendency, to treat hermeneutics as a method of textual exegesis, is a counter-turning promoted by Dilthey's closer disciple, Paul Ricoeur.

We are indebted past any possibility of repayment to Ricoeur's extraordinary contributions to, critiques and extensions of hermeneutics, and so I want to emphasize that this is a lonely quarrel I have with him. But the greater part of Gadamer's lifelong effort was devoted to honoring the liberal human competency to communicate, deliberate, and come to terms. It is not enough to say that explanatory analysis is subordinate to interpretation if that analysis is given a privileged authority. Our deep competence is first and foremost our ability to communicate with one another and arrive at an understanding, and expertise will only ever serve as a support for this: "I certainly need a great deal of knowledge about language and historical conditions and cultural habits and so on, that is one thing. But to concretize all that in this unique statement or text must recollect all these externalized and objectifiable aspects to live through the meaning in concrete fullness, that is quite another thing." 34 In the end, the debate about explanation and understanding is about a very basic existential, perhaps even biographical, difference. 35 For Gadamer explanation and understanding are not co-equal. Explanation is a discursive act (an act of description, a support for a claim, etc.), a technique of logic (the 


\section{THE SCHOLAR AND THE PUB CRAWLER}

clarification of warrants, etc.), a stage in a process of coming to terms. It is only one among a repertoire of discursive competencies (including, for instance, interrogation, imaginative representation, rumination) that stand in the service of better understanding. It is thus secondary to understanding, which is either a goal in itself, or a prelude to action. To put explanation and understanding in a dialectical relationship, as Ricoeur does, is to mistake a secondary function for a primary mode of being.

\section{Denison University}

\section{Notes}

${ }^{1}$ Ricoeur's summary of Habermas's critique can be found in an extended footnote in Paul Ricoeur, Hermeneutics and the Human Sciences, John B. Thompson, ed. and trans. (Cambridge: Cambridge University Press, 1981), 299.

${ }^{2}$ Hans-Georg Gadamer, Reason in the Age of Science [Reason], trans. Frederick G. Lawrence (Cambridge: MIT Press, 1981), 1. Over the course of his career, Gadamer expressed any number of formulations for the theorypractice relation of hermeneutics and hermeneutic philosophy, but this claim is a dominant one.

${ }^{3}$ Hans-Georg Gadamer, Truth and Method, $2^{\text {nd }}$ rev. ed., trans. Joel Weinsheimer and Donald G. Marshall (New York: Continuum Press, 1993), xxivv.

4 "Aristotle and the Ethic of Imperatives," in Action and Contemplation, Robert C. Bartlett and Susan D. Collins, eds. (Albany: SUNY Press), 63.

${ }^{5}$ Gadamer, "Aristotle and the Ethic of Imperatives," 58.

6 Gadamer, Reason, 92.

${ }^{7}$ Gadamer, Reason, 112.

${ }^{8}$ Gadamer returns to hermeneutics the concepts of claim (Aussage) and judgment (Urteil) that have been deracinated by logical positivism: "It is not just that the statement or judgment is merely one particular form among the many other linguistic orientations - they themselves remain bound up with man's life orientation" (TM 453/WM 457). The German original reads: "Nicht nur, daß die Aussage und das Urteil eine bloße Sonderform innerhalb der Mannigfaltigkeit sprachlichen Verhaltens ist — sie bleibt selber in das Lebensverhalten verwoben." Günter Figal develops his own theory of "hermeneutic objectivity," but the idea seems to me already implicit in Heidegger and Gadamer. Günter Figal, "Life As Understanding," Research in Phenomenology 34 (2004): 20-31.

${ }^{9}$ Gadamer, Truth and Method, 443. The German text reads: "Sich zur Welt verhalten erfordert aber, sich von dem von der Welt her Begegnenden so weit freihalten, daß man es vor sich stellen kann, wie es ist" (WM 447). 


\section{JOHN ARTHOS}

${ }^{10}$ Gadamer, Truth and Method, 453 (translation modified).

${ }^{11}$ Paul Ricoeur, "The Conflict of Interpretations: Debate with HansGeorg Gadamer" [Debate], in A Ricoeur Reader, Mario J. Valdes, ed. (Toronto: University of Toronto Press, 1991), 236.

${ }^{12}$ My topic is controversial, so it is important to make clear at the outset what I am not arguing. Paul Ricoeur performed the invaluable service of working out for hermeneutics the proper approach to and valuation of objectivity. Gadamer was so absorbed in providing a counterweight to methodologism and in uncovering the prejudices of objectivism or verificationism that he neglected a proper defense of logos as reason. He was more concerned to find the proximity between the speculative and the everyday than to work out their tensions. Also, I do not challenge the reciprocity of explanation and understanding. We can all embrace Ricoeur's aphorism that "to explain more in order to understand better." There is a question of whether these two stand in a properly dialectical relation to each other, but there is no question that they work in each other's service.

${ }^{13}$ Ricoeur, Hermeneutics and the Human Sciences, 82.

${ }^{14}$ Ricoeur, Hermeneutics and the Human Sciences, 152.

${ }^{15}$ Ricoeur, Hermeneutics and the Human Sciences, 152.

${ }^{16}$ Please note here that my argument is about the relative position of explanation and understanding, not about the legitimacy of explanation or distanciation.

${ }^{17}$ Ricoeur, Hermeneutics and the Human Sciences, 184-5.

${ }^{18}$ Ricoeur, Hermeneutics and the Human Sciences, 182-3.

${ }^{19}$ Ricoeur, Hermeneutics and the Human Sciences, 93.

${ }^{20}$ Ricoeur, Debate, 237.

${ }^{21}$ Ricoeur, Debate, 222-223.

${ }^{22}$ Hans-Georg Gadamer, A Century of Philosophy, Rod Coltman, trans.

(New York: Continuum, 2004), 51.

${ }^{23}$ Hans-Georg Gadamer, "On the Political Incompetence of Philosophy,” Diogenes 46 (2) (1998): 5.

${ }^{24}$ Gadamer, "On the Political Incompetence of Philosophy," 4-5.

${ }^{25}$ Gadamer, "On the Political Incompetence of Philosophy," 6.

${ }^{26}$ Gadamer, "On the Political Incompetence of Philosophy," 11.

${ }^{27}$ Gadamer, "On the Political Incompetence of Philosophy," 5.

${ }^{28}$ Ricoeur, Debate, 9.

${ }^{29}$ Ricoeur, Debate, 18-19.

${ }^{30}$ Paul Ricoeur, Interpretation Theory: Discourse and the Surplus of Meaning, (Fort Worth, Texas: Texas Christian University Press, 1976), 74, 78.

${ }^{31}$ Ricoeur, Interpretation Theory: Discourse and the Surplus of Meaning, 84.

${ }^{32}$ Ricoeur, Interpretation Theory: Discourse and the Surplus of Meaning, 85.

${ }^{33}$ Schleiermacher represented both the culmination of the understanding of hermeneutics as a specialized technique, and the abstraction 


\section{THE SCHOLAR AND THE PUB CRAWLER}

of hermeneutics away from this function.

${ }^{34}$ Ricoeur, Debate, 236-7.

35 The title references somewhat tongue-in-cheek Ricoeur's and Gadamer's privileged modes of intellectual engagement, because I believe this has a bearing on their positions. Ricoeur was a prototypical scholar-writer who was leery of extemporaneous dialogue about his ideas. An interviewer began a discussion with Ricoeur on this topic:

Interviewer: "Paul Ricoeur, you are above all a man of writing. Nevertheless, you were kind enough to accept the principle of a series of conversations. What does this represent for you?"

Ricoeur: "I wish to say first that this is a form of language use that I fear a great deal, because I am indeed a person who writes but also someone who rewrites, who crosses out. I am usually, therefore, mistrustful of improvisation.” Paul Ricoeur, Critique and Conviction, Kathleen Blamey, trans. (New York: Columbia University Press, 1998).

Gadamer was the opposite. Some believe Truth and Method was largely a work of extemporaneous dictation to his wife. Certainly working out his theories with students and colleagues in open conversation was at the core of Gadamer's modus operandi. Like Socrates, he could outlast almost anyone in pub talk long into the night, and his extemporaneous skills as a lecturer are legendary. 